\title{
Review Analisis Teknologi Degradasi Limbah Minyak Bumi untuk Mengurangi Pencemaran Air Laut di Indonesia
}

\author{
Iffat Ganjar Fadhila Prakasita ${ }^{1)}$ dan Ria Wulansarie ${ }^{2)}$ \\ 1,2) Jurusan Teknik Kimia, Fakultas Teknik, Universitas Negeri Semarang, \\ Sekaran, Gunungpati, Semarang 50229 \\ e-mail: iffatpras@gmail.com
}

\begin{abstract}
ABSTRAK
Penentuan metode degradasi minyak bumi yang tepat sangat diperlukan untuk mengatasi pencemaran tumpahan minyak bumi khususnya di air laut Indonesia. Metode degradasi limbah minyak bumi yang digunakan adalah metode degradasi secara kimia dan biologi yaitu menggunakan surfaktan nonionik (Tween 80 dan Brij 35) dan bioremediasi menggunakan bakteri Pseudomonas aeruginosa. Variabel yang digunakan pada metode degradasi kimia dengan surfaktan nonionik adalah variasi konsentrasi $0.0000,0.0025,0.0050,0.0075,0.0100,0.0125,0.0150,0.0175,0.0200,0.0225,0.0250,0.0275,0.0300$, $0.0350,0.0400 \%(\mathrm{v} / \mathrm{v})$ dan variasi pengadukan untuk menguji stabilitas emulsi minyak bumi dengan laju 100, 120, dan $140 \mathrm{rpm}$ selama $1 \mathrm{jam}$. Variabel yang digunakan pada metode bioremediasi adalah konsentrasi penambahan mikroba Pseudomonas aeruginosa sebanyak $0 \% ; 1 \% ; 3 \%(\mathrm{v} / \mathrm{v})$, konsentrasi cemaran minyak bumi 1000 ppm dan 1500 ppm serta media aerasi dan media tanpa aerasi. Hasil degradasi minyak bumi terbaik didapatkan pada metode bioremediasi menggunakan Pseudomonas aeruginosa dengan konsentrasi bakteri sebanyak 3\% (v/v) pada media teraerasi dan konsentrasi cemaran minyak 1000 ppm dengan \% biodegradasi TPH yang dicapai sebesar 100\% dalam waktu 21 hari.
\end{abstract}

Kata kunci: bioremediasi; degradasi; TPH

\begin{abstract}
Determination of appropriate petroleum degradation method is needed to overcome the contamination of oil spills, especially in Indonesia's seawater. The method of degradation of petroleum waste used is chemical and biological degradation method using nonionic surfactant (Tween 80 and Brij 35) and bioremediation using Pseudomonas aeruginosa bacteria. Variable used in chemical degradation method with nonionic surfactant is concentration variation $0.0000 ; 0.0025 ; 0.0050 ; 0.0075 ; 0.0100 ; 0.0125 ; 0.0150 ; 0.0175 ; 0.0200 ; 0.0225 ; 0.0250 ; 0.0275 ; 0.0300$; $0.0350,0.0400 \%(v / v)$ and stirring variations to test the stability of petroleum emulsion at rates 100, 120, and 140 rpm for 1 hour. The variable used in the bioremediation method is the concentration of Pseudomonas aeruginosa addition of $0 \% ; 1 \% ; 3 \%(v / v)$, the concentration of petroleum contamination 1000 ppm and 1500 ppm also aeration medium and aeration non medium. The best petroleum degradation results were obtained in bioremediation method using Pseudomonas aeruginosa with bacterial concentration of $3 \%(v / v)$ in aerated media and concentration of 1000 ppm oil contamination with TPH biodegradation achieved at 100\% within 21 days.
\end{abstract}

\section{Keywords : bioremediation; degradation; TPH}

\section{PENDAHULUAN}

Peningkatan kebutuhan bahan bakar minyak mengakibatkan peningkatan eksplo- rasi dan pengolahannya. Pada kenyataannya, produksi dan konsumsi produk minyak bumi semakin meningkat di seluruh dunia dan pencemaran minyak secara langsung akan 
meningkat juga. Pencemaran air laut oleh minyak bumi disebabkan karena tumpahnya minyak bumi pada proses pengolahan, produksi, distribusi maupun penggunaannya sehingga komponen-komponen minyak bumi terlepas ke perairan, seperti misalnya kebocoran tangker minyak bumi, jalur pipa transmisi, kebocoran karena peralatan yang tidak terawat dengan baik, proses produksi yang tidak baik, ataupun pembuangan sisa minyak bumi [1]. Dampak ekologis yang ditimbulkan dari pencemaran minyak bumi di laut, yaitu: pencemaran laut yang berasal dari tumpahan minyak akan merusak ekosistem laut antara lain plankton (fitoplanktonzooplankton) dan nekton. Pencemaran minyak di laut sebagai akibat dari tumpahan minyak dapat mempengaruhi tingkat intensitas fotosintesis.

Penanganan kondisi lingkungan yang tercemari minyak bumi dapat dilakukan secara fisika, kimia dan biologi. Salah satu metode alternatif pengolahan limbah minyak bumi secara kimia adalah menggunakan surfaktan nonionik sedangkan metode biologi dapat dilakukan menggunanakan metode bioremidiasi.

Bioremediasi merupakan teknologi yang menggunakan mikroba untuk mengolah (cleaning) hidrokarbon minyak bumi dari kontaminan melalui mekanisme biodegradasi alamiah (intrinsic bioremediation) atau meningkatkan mekanisme biodegradasi alamiah dengan menambahkan mikroba, nutrien, donor elektron dan atau akseptor elektron (enhanced bioremediation) [2]. Bioremidiasi menggunakan isolate bakteri Pseudomonas aeruginosa dapat menu-runkan Total Petroleum Hidrokarbon (TPH) pada tanah terkonta-minasi minyak bumi dengan orde reaksi degradasi limbah minyak bumi sebesar 0,904 dengan nilai konstanta reaksinya sebesar 0,0073 per hari [3].
Penanganan pencemaaran lingkungan secara kimia dapat dilakukan menggunakan surfaktan nonionik. Surfaktan nonionik adalah bahan esensial yang tidak beracun dengan konsentrasi ambang batas lebih dari $100 \mathrm{~g} / \mathrm{kg}$ dan bersifat biodegradabel [4]. Tujuan dari penelitian ini adalah mengetahui metode degradasi minyak bumi yang efektif melalui uji degradasi dengan variasi TPH.

\section{METODE PENELITIAN}

\section{Degradasi Minyak Bumi}

Degradasi minyak bumi dapat dilakukan dengan beberapa metode. Pada artikel ini akan dibahas metode degradasi limbah minyak bumi yaitu degradasi secara biologi melalui bioremediasi menggunakan bakteri dan degradasi secara kimia menggunakan surfaktan nonionik.

\section{Bioremediasi menggunakan bakteri Pseudomonas aeruginosa}

Metode degradasi secara biologi dapat dilakukan menggunakan mikro-organisme pendegradasi minyak bumi. Bakteri yang umum digunakan dalam proses bioremidiasi limbah pengilangan minyak bumi adalah bakteri hidrokarbonoklastik. Bakteri ini memiliki kemampuan men-degradasi senyawa hidrokarbon yang terdapat dalam limbah. Secara alami mikroorganisme ini memiliki kemampuan untuk mengikat, mengemulsi, mentranspor, dan mendegradasi hidrokarbon. Bakteri ini mendegradasi senyawa hidrokarbon dengan cara memotong rantai hidrokarbon tersebut menjadi lebih pendek dengan melibatkan berbagai enzim [5]. Bakteri hidrokarbonoklastik dapat diisolasi dari lingkungan yang tercemar hidrokarbon. Hasil identifikasi dari ke 10 isolat bakteri petrofilik 4 isolat termasuk Psendomonas, 4 isolat termasuk Bacillus, 1 isolat termasuk genus Micrococcus serta 1 isolat termasuk 
Flavobacterium [3]. Hasil penelitian lain menunjukan hasil isolasi bakteri dari limbah sludge minyak bumi ataupun dari areal terkontaminasi minyak bumi umumnya merupakan jenis bakteri peteofilik yang didominasi oleh genus Pseudomonas [6].

\section{HASIL DAN PEMBAHASAN}

\section{Pengaruh Populasi Bakteri Pseudomonas aeruginosa terhadap Nilai TPH}

Pertumbuhan mikroorganisme merupakan indikator terjadinya proses biodegradasi. Berikut merupakan grafik hubungan TPH dengan jumlah sel bakteri Peudomonas aeruginosa [7]:

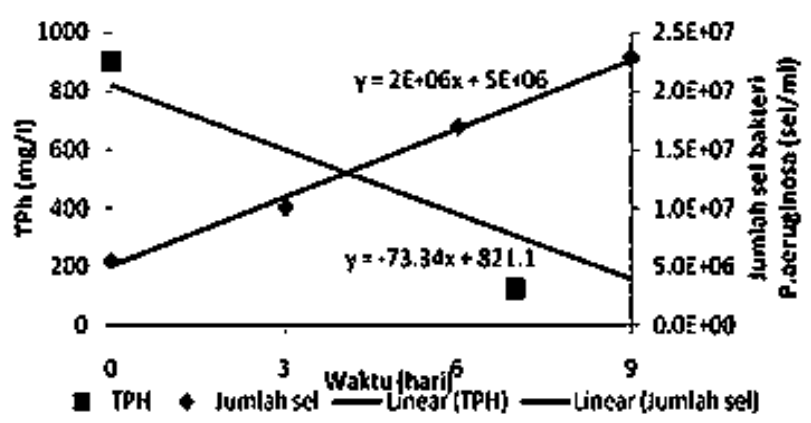

Gambar 1. Hubungan TPH dengan jumlah sel bakteri P.aeruginosa

Pada gambar 4 terlihat bahwa, pada interval waktu hari ke-0 hingga hari ke-9 (pada fase log), terjadi penurunan TPH yang cukup signifikan yaitu dari $899 \mathrm{mg} / \mathrm{l}$ sampai \pm 100 $\mathrm{mg} / \mathrm{l}$. Laju penurunan TPH ditunjukkan pada slope kurva TPH vs $t$ dengan persamaan garis $\mathrm{y}=-73,34 \mathrm{x}+821,1$ $\mathrm{mg} /$ l.hari. Sedangkan nilai jumlah sel bakteri mengalami kenaikan dari 5,56 x $106 \mathrm{sel} / \mathrm{ml}$ hingga 2,28 x $107 \mathrm{sel} / \mathrm{ml}$. Laju pertumbuhan bakteri ditunjukkan oleh slope pada kurva jumlah sel vs $\mathrm{t}$ dengan persamaan garis $\mathrm{y}=(2$ $x$ 106) $x+(5 x$ 106 $)$ sel/ml.hari. Hal ini berarti kenaikan rate pertumbuhan bakteri diikuti dengan penurunan konsentrasi TPH dari hari ke hari.
Tabel 1. Perbandingan Slope dan Intercept pada Fase Log

\begin{tabular}{cccc}
\hline $\begin{array}{c}\text { Bio- } \\
\text { reaktor }\end{array}$ & $\begin{array}{c}\text { Persamaan Garis } \\
\text { regresi linier } \\
\text { TPH vs waktu } \\
\text { pada fase log }\end{array}$ & $\begin{array}{c}\text { Rate } \\
\text { Penurunan } \\
\text { TPH } \\
\text { (mg/1 hari) }\end{array}$ & $\begin{array}{c}\text { Nilai TPH } \\
\text { awal (mg/1) }\end{array}$ \\
\hline 3 & $\mathrm{y}=-38,42 \mathrm{x}+741$ & $-38,42$ & 741 \\
\hline 4 & $\mathrm{y}=-61,81 \mathrm{x}+768,1$ & $-61,81$ & 768,1 \\
\hline 5 & $\mathrm{y}=-51 \mathrm{x}+816,3$ & -51 & 816,3 \\
\hline 6 & $\mathrm{y}=-73,34 \mathrm{x}+821,1$ & $-73,34$ & 821,1 \\
\hline 9 & $\mathrm{y}=-51,42 \mathrm{x}+1294$ & $-51,42$ & 1294 \\
\hline 10 & $\mathrm{y}=-75,71 \mathrm{x}+1280$ & $-75,71$ & 1280 \\
\hline 11 & $\mathrm{y}=-61,81 \mathrm{x}+1261$ & $-57,42$ & 1261 \\
\hline 12 & $\mathrm{y}=-87,14 \mathrm{x}+1298$ & $-87,14$ & 1298 \\
\hline
\end{tabular}

Pada tabel 1 dapat dilihat dari perbandingan perlakuan pada bioreaktor 1 hingga bioreaktor 12, terlihat slope yang paling besar penurunannya adalah treatment pada reaktor dengan penambahan $3 \% \mathrm{v} / \mathrm{v}$ Pseudomonas aeruginosa, media teraerasi dan konsentrasi cemaran minyak $1500 \mathrm{mg} / \mathrm{l}$ minyak bumi, yaitu bioreaktor 12 .

Dari penelitian lain yang dilakukan oleh Bambang (2013) [3] didapatkan hasil bahwa bakteri petrofilik lokal mampu menurunkan TPH sebesar 91,04\% selama enam minggu dengan metode biopile. Sedangkan penelitian yang dilakukan oleh Astri (2007) [2], penyisihan rata-rata minyak bumi untuk Pseudomonas aeruginosa sebesar 90\%, Aeromonas hydro-phila sebesar $88 \%$, Agrobacterium radio-bacter sebesar 79\%, penggabungan ketiga bakteri 84\%, dan mikroorganisme konsor-sium sebesar 92\%. Hal ini menun-jukkan bahwa kemampuan degradasi limbah minyak bumi terbaik dapat dilakukan oleh bakteri Pseudomonas.

\section{Penambahan Surfaktan Nonionik}

Degradasi limbah minyak bumi secara kimia dapat dilakukan menggunakan surfaktan nonionik. Jenis surfaktan nonionik yang digunakan adalah Tween 80 dan Brij 35 . Degradasi ini terbagi atas tiga tahap, yaitu menentuan tegangan permukaan surfaktan nonionik menguji pengaruh konsentrasi 
surfaktan terhadap stabilitas emulsi, serta memvariasikan laju pengadukan. Parameter yang ditentukan antara lain TPH padat, TPH cair, $\mathrm{pH}$, dan COD.

\section{Pengaruh Penambahan Surfaktan terhadap Tegangan Permukaan}

Pengukuran tegangan permukaan surfaktan dilakukan dengan metode cincin Du Noőy menggunakan Surface Tensiometer Model 20. Metode ini didasarkan pada penentuan gaya yang diperlukan untuk menarik cincin Pt-Ir dari permukaan cairan. Tegangan permukaan diukur berdasarkan gaya yang diperlukan untuk menarik cincin yaitu pda saat terjadinya titik pecah gelembung setelah dilakukan pengukuran menggunakan cincin Pt-Ir. Gaya yang diperlukan untuk menarik cincin sebanding dengan tegangan permukaan surfaktan [8]. Hasil penelitian menunjukkan bahwa tegangan permukaan tanpa penambahan surfaktan mempunyai nilai lebih tinggi dibandingkan menggunakan penam-bahan surfaktan.

\section{Pengaruh Konsentrasi Surfaktan pada Stabilitas Emulsi}

Konsentrasi surfaktan yang diguna-kan untuk mengamati pengaruh konsentrasi surfaktan terhadap stabilitas emulsi didasarkan pada nilai tegangan permukaan terkecil dari surfaktan. Dari penelitian yang dilakukan oleh Charlena tahun 2009, digunakan nilai tegangan permukaan 49.58 dyne/ $\mathrm{cm}$ untuk Tween $80(0.0175 \%)$ dan 31.29 dyne/cm untuk Brij 35 (0.0175\%) pada uji pengaruh konsentrasi surfaktan terhadap stabilitas emulsi. Uji pengaruh pengadukan terhadap analisis $\mathrm{pH}, \mathrm{TPH}$ padat, TPH cair, dan COD dilakukan dengan variasi laju pengadukan 100, 120, dan $140 \mathrm{rpm}$ selama 1 untuk masing-masing surfaktan. Masing-masing perlakuan diukur $\mathrm{pH}$, TPH padat, TPH cair, dan CODnya.

Limbah minyak diemulsikan menggunakan ultrasonic homogenizer dan diukur turbiditasnya turbidimeter. Stabilitas emulsi dihitung dengan rumus sebagai berikut:

$$
\% \text { Stabilitas emulsi }=\frac{\text { turbiditas akhir }}{\text { turbiditas awal }} \times 100 \%
$$

Dari hasil penelitian menunjukan pengukuran stabilitas emulsi pada lima konsentrasi berbeda dengan membandingkan kekeruhan emulsi sebelum dan sesudah sentrifugasi hanya memberikan perubahan stabilitas emulsi sedikit saja. Stabilitas emulsi maksimum untuk Tween 80 sebesar 0.24\% pada konsentrasi $0.0175 \%$, sedangkan Brij 35 sebesar $0.22 \%$ pada konsentrasi $0.0150 \%$. Hal ini berarti kenaikan stabilitas emulsi disebabkan karena molekul-molekul surfaktan teradsorpsi pada antarmuka air dan minyak. Adsorpsi ini terjadi karena gugus hidrofobik molekul surfaktan mengarah ke minyak untuk menghindari kontak dengan air sehingga terjadi tarik menarik antara minyak dan gugus hidrofobik, sedangkan gugus hirofilik dari molekul surfaktan tarik-menarik dengan air. Adsorpsi yang terjadi ini menurunkan tegangan antarmuka minyak-air sehingga meningkatkan stabilitas emulsi yang terbentuk.

\section{Pengaruh Pengadukan Terhadap Nilai TPH}

TPH (Total Petroleum Hydrocarbons) menggambarkan jumlah hidrokarbon dengan berbagai macam panjang rantainya tanpa melihat jenisnya yaitu alisiklik, aromatik atau alifatik [9]. Nilai TPH pada baku mutu air laut daerah pelabuhan ditentukan dibawah 5 $\mathrm{mg} /$ liter atau $5 \mathrm{ppm}$, sedangkan untuk biota laut dibawah $1 \mathrm{mg} /$ liter atau $1 \mathrm{ppm}$ [10]. 
TPH merupakan parameter yang paling tepat untuk menggambarkan biodegradasi limbah minyak bumi. Penambahan surfaktan pada degradasi minyak bumi akan meningkatkan jumlah minyak yang terdispersi dalam air karena biodegradasi terjadi pada bagian antarmuka air dan minyak. Berikut merupakan grafik hasil pengukuran TPH [8]:

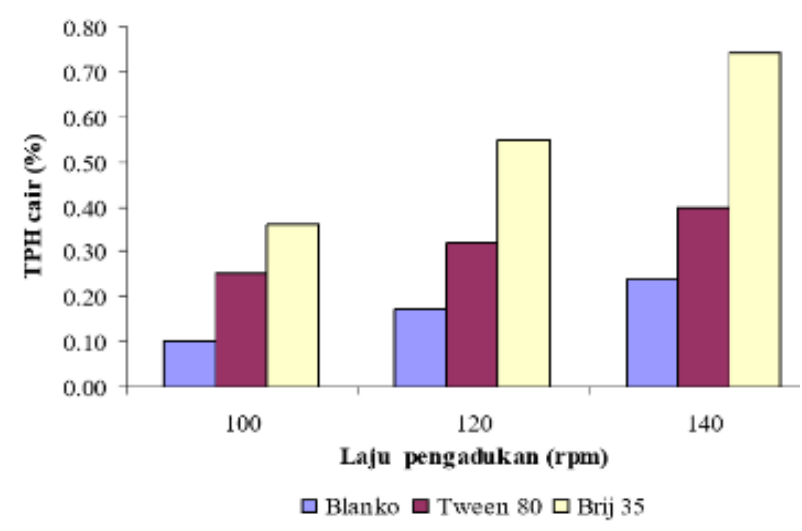

Gambar 2. Hasil pengukuran TPH cair

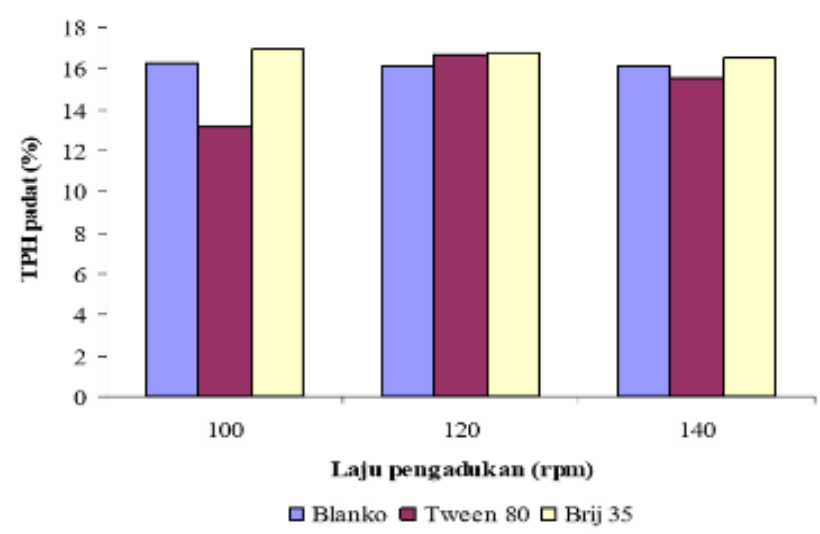

Gambar 3. Hasil pengukuran TPH padat

Dari grafik dapat dilihat, pada blanko nilai TPH cair meningkat dengan bertambahnya laju pengadukan, tetapi hanya memberikan sedikit kenaikan nilai TPH cair. Sedangkan dengan penambahan surfaktan, kenaikan nilai TPH cair semakin besar seiring dengan penambahan laju pengadukan. Nilai TPH cair dengan penambahan surfaktan Brij $35(0.0150 \%)$ lebih tinggi dibandingkan Tween $80(0.0175 \%)$. Hasil degradasi TPH pada penambahan Brij 35 mencapai 99,26\% sedangkan pada penambahan Tween 80 mencapai 99,60\%. Hal ini berarti dispersi minyak dalam air juga lebih tinggi. Semakin meningkatnya nilai TPH cair, maka nilai TPH padatnya akan menurun (Gambar 3). Semakin bertambahnya laju pengadukan, maka minyak yang terdispersi dalam air semakin meningkat sehingga menyebabkan nilai TPH padat menurun, yang berarti bahwa minyak terdegradasi dengan baik.

\section{Pengaruh Pengadukan Terhadap Nilai COD}

COD merupakan salah satu cara untuk menghitung kandungan bahan organik total. Pengukuran nilai COD dilakukan untuk mengetahui pengaruh penambahan surfaktan dan laju pengadukan terhadap jumlah senyawa organik yang terkandung dalam limbah minyak bumi. Berikut grafik hasil pengukuran COD [9] :

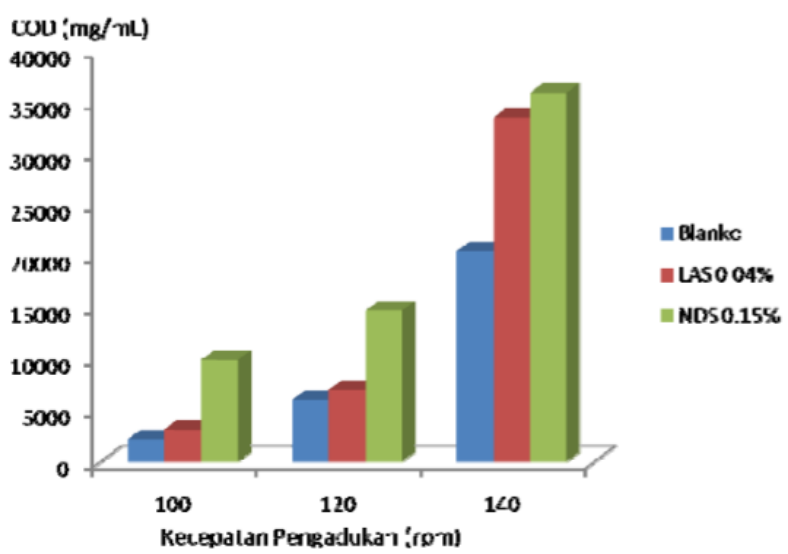

Gambar 4. Hasil pengukuran COD

Dari gambar 4 menunjukkan semakin tinggi laju pengadukan, nilai CODnya akan semakin besar. Hal ini berarti semakin tinggi laju pengadukan, semakin banyak senyawa organik dari limbah minyak bumi yang masuk dalam air. Nilai COD blanko lebih rendah dibandingkan penambahan surfaktan pada Gambar 4. Hal ini menunjukkan penam- 
bahan surfaktan memberikan pengaruh yang besar terhadap kandungan senyawa organik dari limbah minyak bumi yang ada dalam air.

Dari beberapa penelitian yang dilakukan sebelumnya, dapat dibuktikan bahwa penambahan surfaktan nonionik dapat membantu mengoptimalkan degradasi limbah minyak bumi dalam medium perairan. Dispersi minyak bumi ke dalam medium air akan lebih mudah bila ditambahkan surfaktan. Surfaktan dapat mengikat minyak yang bersifat non-polar dan di sisi lain surfaktan juga dapat mengikat air yang bersifat polar. Surfaktan dapat memudahkan kontak antara mikroorganisme dengan sumber karbon dari minyak bumi sebagai makanannya, sehingga meningkatkan efektivitas degradasi limbah melalui metode bioremediasi.

\section{KESIMPULAN}

Degradasi minyak bumi dapat dilakukan dengan bioremediasi menggunakan isolat bakteri. Bakteri yang paling efektif digunakan adalah bakteri genus Pseudomonas yaitu spesies Pseudomonas aeruginos karena terbukti pada penelitian yang dilakukan dengan penambahan bakteri $3 \%(\mathrm{v} / \mathrm{v})$, media teraerasi dan konsentrasi cemaran minyak bumi 1000 ppm mampu menghasilkan biodegradasi TPH mencapai $100 \%$. Metode degradasi menggunakan bakteri Pseudomonas aeruginosa dapat dikombinasikan dengan degradasi menggunakan surfaktan nonionik dengan hasil gradasi TPH hanya sebesar 99,26\% pada penambahan Brij 35 dan 99,60 $\%$ pada pada penambahan Tween 80 sehingga proses degradasi limbah minyak bumi menjadi efektif dan lebih optimal.

\section{DAFTAR PUSTAKA}

[1] Hartanto, Benny. 2008. Oil Spill (Tumpahan Minyak) di Laut dan Beberapa kasus di Indonesia. Bahari Jogja Vol.VIII No.12.

[2] Nugroho, Astri. 2007. Pertumbuban Konsorsium Isolat Bakteri Asal Benakat pada Media Minyak Bumi Bersalinitas Tinggi: Studi Kasus Biodegradasi Minyak Bumi Skala Laboratorium. Jakarta: Universitas Trisakti.

[3] Yudono, Bambang. 2013. Kinetika Degradasi Limbah Minyak Bumi Menggunakan Sinergi Bakteri Konsorsium (Microccoccus sp, Pseudomonas pseudomallei, Pseudomonas pseudoalcaligenes dan Bacillus sp) dan Rumput Eleusine Indica (L.) Gaertn. Palembang: Universitas Sriwijaya.

[4] Clark J. 2004. Mechanism, chemistry, and physics dispersants in oil spill response. Presentation to NRC committee on understanding oil spill dispersants: efficacy and effects. Exxon Mobile Research ang Engineering.

[5] Zam, Syukria Ikhsan. 2011. Bioremediasi Tanah yang Tercemar Limbah Pengilangan Minyak Bumi Secara In Vitro pada Konsentrasi Ph Berbeda. Riau: UIN Sultan Syarif Kasim.

[6] Munawar, Aditiawati P, \& Astuti DI, 2012. Sequential Isolation of Saturated, Aromatic, Resinic And Asphaltic Fractions Degrading Bacteria From Oil Contaminated Soil In South Sumatra. Makara Journal of Science. 16(1): 58-64.

[7] Yulia, Lusiana Riska. 2012. Bioremediasi Air Laut Terkontaminasi Minyak Bumi dengan Menggunakan Bakteri Pseudomonas aeruginosa. Surabaya: Institut Teknologi Sepuluh Nopember.

[8] Charlena. 2009. Profil Kelarutan Limbah Minyak Bumi dalam Air Akibat Pengaruh 
Surfaktan Nonionik dan Laju Pengadukan.

Bogor: Institut Pertanian Bogor.

[9] Sjahrizal, Ahmad. 2011. Profil Kelarutan Limbah Minyak Bumi dalam Air dengan Penambahan Surfaktan Anionik dan Laju Pengadukan. Bogor: Institut Pertanian Bogor.

[10] Keputusan Menteri Lingkungan Hidup no. 51 tahun 2004. 